\title{
A study on mobile health applications in dermatology
}

\section{Dermatolojide mobil sağlık uygullamaları üzerine birr çalışma}

\author{
Mustafa Tosun ${ }^{1}$, Nurperihan Tosun²
}

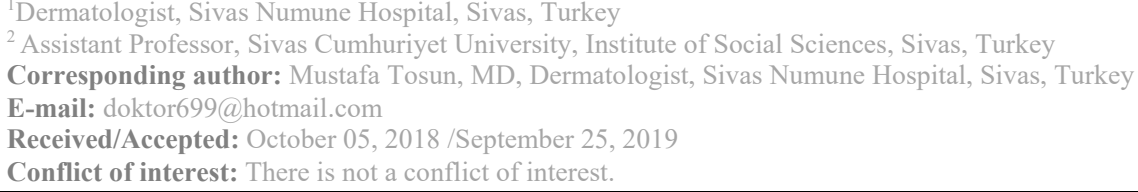

\begin{abstract}
SUMMARY
Objective: The purpose of this study is to assess the profile of mobile health applications in the field of dermatology.

Method: The data of the study performed in cross-sectional type have been obtained from the App Store between August - September 2017. All applications in health, fitness and medical categories in App Store, have been scanned according to the criteria specified and those which are related to dermatology have been included in the study. A total of 219 applications have been examined in total.

Results: When the content of health applications in dermatology is examined, 70 (32\%) of 219 applications are the ones in the form of questions and answers and data sharing towards increasing the level of knowledge and education among physicians and medical students. When it was tried to determine to which are the mobile applications were directed, it was found that of the first three applications developed the most, 160 (73.1\%) were in the field of general dermatology, $21(9.6 \%)$ were in Dermatocosmetology and $13(5.9 \%)$ were in Dermatoscopy, and the least developed application was in the field of Dermatology + Plastic Surgery with $2(0.9 \%)$. When the status of whether the application is paid examined, it was determined that $145(66.2 \%)$ were free, and when we evaluate their languages, it was determined that 218 (99.5\%) applications were in English.

Conclusions: In general, dissemination of these applications, which make it easy for the physicians, medical students, patients and those who access the applications to reach up to date information and to follow and manage the disease and health status in the field of dermatology could be considered as a positive finding.
\end{abstract}

Mustafa Tosun

Nurperihan Tosun

Keywords: Applications, smartphone, dermatology

ÖZET

Amaç: Bu çalışmanın amacı dermatoloji alanındaki mobil sağlık uygulamalarının profilinin değerlendirilmesidir. Yöntem: Kesitsel tipte yapılan çalışmanın verileri, Ağustos-Eylül 2017 tarihlerinde, App Store'dan elde edilmiştir. App Store'daki sağlık, fitness ve tıp kategorilerindeki yer alan bütün uygulamalar, belirlenen kriterlere göre taranmış ve dermatoloji ile ilgili olanlar çalışmaya dahil edilmiştir. Toplamda 219 uygulama incelenmiştir.

Bulgular: Dermatoloji alanındaki sağlık uygulamalarının içeriği incelendiğinde, 219 uygulamanın 70 (\%32)'inde hekimlerin ve tıp öğrencilerinin eğitimi ve bilgi düzeylerini arttırmaya yönelik soru-cevap ve vaka paylaşımı şeklinde olan uygulamalar tespit edildi. Mobil uygulamaların hangi alana yönelik olduğu saptanmaya çalışıldığında ise, en çok 
geliştirilen uygulamanın $160(\% 73,1)$ 'ının genel dermatoloji, en az geliştirilen uygulamanın ise $2(\% 0,9)$ uygulama ile Dermatoloji+Plastik Cerrahi alanında olduğu bulundu. Uygulamaların ücretli olma durumu incelendiğinde ise 145 $(\% 66,2)$ 'inin ücretsiz olduğu ve $218(\% 99,5)$ uygulamanın dilinin İngilizce olduğu tespit edildi.

Sonuç: Genel olarak hekimlerin, tıp öğrencilerinin, hastaların ve uygulamalara erişmek isteyen kişilerin hastalık ve sağlık durumlarını takip etme, yönetme, güncel bilgilere ulaşma ve bilgi düzeylerini artırmalarını kolaylaştıran bu uygulamaların, dermatoloji alanında da yaygınlaşması olumlu bir bulgu olarak değerlendirilebilir.

Anahtar sözcükler: Uygulamalar, akıllı telefon, dermatoloji

\section{INTRODUCTION}

Today, increasing health expenditures, prolongation of life expectancy and chronic diseases, barriers to access to health services due to long waiting times, factors such as lack of desired levels of health workers per patient are among the problems related to health systems of countries. In addition to these problems, individuals have become conscious in health seeking and managing behaviors as in all subjects with increasing education level. Mobile technologies have the potential to close the systemic gaps necessary to increase access to health care, especially the use of inadequate care of the population. Mobile health applications, designed to improve health care delivery processes, are used to serve health professionals in matters such as training, diagnostic support and patient management, or to communicate between patients and health care services 1,2 . According to Turkish Statistical Institute 2018 household data, the rate of using mobile phones or smartphones with internet access was $79.4 \%{ }^{3}$. In this sense it is thought that mobile health applications supported by smartphones will have positive effects on the health outcomes of the society when they are used to monitor and manage the health and illness conditions of individuals.

New developments in technology have developed accurate diagnosis and treatment opportunities in the field of medicine and provided an opportunity to establish a good dialogue between physicians and patients. Developments in telehealth and telemedicine also affected the applications in the field of dermatology as in the case of other medical branches. Dissemination of the communication technology to every field of our life enabled widespread use in patient-physician communication in addition to their impact on diagnosis and treatment in the field of medicine. Although not replacing the physical examination and patient follow-up, due to its advantages such as providing the physician with the ability to access patient information in a faster and easier manner and preventing the patients from being deprived of physician follow up for various reasons, telehealth and telemedicine applications have been widely used in many developed countries today ${ }^{4}$.

The World Health Organization has defined mobile health as all complementary and innovative health practices that utilize mobile communications technology and infrastructure to enhance the effectiveness and function of the existing health system, such as health promotion, remote disease management, health data collection, and early warning systems ${ }^{5}$.

New devices that are called the "smartphones", in addition to being a means of communication, contain various functions such as a powerful computer, camera, video / voice recorder device, $\mathrm{mp} 3$ player, radio and navigation that could be held in hand. There are various applications that could be rapidly downloaded to these phones, which are briefly called "Apps." It is observed that the health sciences rapidly adapt to these developments in mobile technologies. There are various medical mobile applications specific to the field. Many apps could be easily downloaded to smartphones free of charge ${ }^{6}$.

Today smartphones are widely used as personal computers in a widespread manner. The fact that these are always open to users is carriable to any place, provide real-time experience to the user provides many facilities, coupled with the increasing processor speed and developed network. Medical applications in the smartphones provide assistance in various issues such as drug reference, support to decide on clinic, and medical education 7. The purpose of this study is to assess the profile of mobile health applications in the field of dermatology.

\section{MATERIAL AND METHODS}

The data of the study performed in cross-sectional type have been obtained from App Store between August - September 2017. All applications in health, fitness and medical categories in App Store, have been scanned according to the criteria specified and those which are related to dermatology have been included in the study. The criteria determined are whether the application is in English and Turkish, the application is free or 
charged, and the type and field of the application. Types of the application were teledermatology, education materials such as book, journal or atlas, sites of physicians or clinics for advertisement purposes, congress pages, applications that increase the level of knowledge of patients related to diseases, applications related to education of physicians and medical students such as quiz, question and answer and case sharing. Applications developed in languages other than English and Turkish were not included in the study.
A total of 219 applications have been examined in total.

\section{RESULTS}

In Table 1, the content of mobile health applications in dermatology was examined, and it was found that $32 \%$ of these were related to the education of physician and medical students, $19.2 \%$ were education materials such as books, journals or atlases, and $18.7 \%$ were related to teledermatology.

Table 1: The Content of Mobile Health Applications in Dermatology

\begin{tabular}{|l|l|l|}
\hline Type of application & $\mathbf{n}$ & $\mathbf{\%}$ \\
\hline $\begin{array}{l}\text { Training of doctors and medical } \\
\text { students }\end{array}$ & 70 & 32,0 \\
\hline Book, journal or atlas & 42 & 19,2 \\
\hline Tele-dermatology & 41 & 18,7 \\
\hline Informing patients & 32 & 14,6 \\
\hline Doctor / clinic sites & 17 & 7,8 \\
\hline congress page & 17 & 7,8 \\
\hline Total & 219 & 100 \\
\hline
\end{tabular}

In Table 2, the area of mobile health applications in dermatology was examined, and it was determined that $73.1 \%$ are related to general dermatology, $9.6 \%$ to dermatocosmetology, and $5.9 \%$ to dermatoscopy.

Table 2: The Area of Mobile Health Applications in Dermatology

\begin{tabular}{|l|l|l|}
\hline Area of application & $\mathbf{n}$ & $\mathbf{\%}$ \\
\hline General Dermatology & 160 & 73,1 \\
\hline Dermatocosmetology & 21 & 9,6 \\
\hline Dermatoscopy & 13 & 5,9 \\
\hline Pediatric Dermatology & 9 & 4,1 \\
\hline Cosmetology & 6 & 2,7 \\
\hline Dermatologic Surgery & 5 & 2,3 \\
\hline Dermatopathology & 3 & 1,4 \\
\hline Dermatology+Plastic Surgery & 2 & 0,9 \\
\hline Total & $\mathbf{2 1 9}$ & $\mathbf{1 0 0 , 0}$ \\
\hline
\end{tabular}


In Table 3, whether the mobile health applications in dermatology were paid was examined, and it was determined that $66.2 \%$ were free and $33.8 \%$ were paid.

Table 3: Charging Status of Mobile Health Applications in Dermatology

\begin{tabular}{|l|l|l|}
\hline Ücret & n & \% \\
\hline Free & 145 & 66,2 \\
\hline Paid & 74 & 33,8 \\
\hline Total & $\mathbf{2 1 9}$ & $\mathbf{1 0 0 , 0}$ \\
\hline
\end{tabular}

When the languages of mobile health applications in dermatology were examined under Table 4, it was determined that $99.5 \%$ were in English and 1 was in Turkish, which applications were the congress page.

Table 4: Languages of Mobile Health Applications in Dermatology

\begin{tabular}{|l|l|l|}
\hline Language & n & \% \\
\hline English & 218 & 99,5 \\
\hline Turkish & 1 & 0,5 \\
\hline Total & $\mathbf{2 1 9}$ & $\mathbf{1 0 0 , 0}$ \\
\hline
\end{tabular}

\section{DISCUSSION}

In this study, it was aimed at demonstrating the mobile applications in the field of dermatology in the App Store and a general profile related to these. 219 applications in English and Turkish languages were reached in the field of dermatology. $32 \%$ of these applications are the ones in the form of questions and answers and data sharing towards increasing the level of knowledge and education among physicians and medical students. When it was tried to determine to which are the mobile applications were directed, it was found that of the first three applications developed the most, $73.1 \%$ were in the field of general dermatology, $9.6 \%$ were in Dermatocosmetology and $5.9 \%$ were in Dermatoscopy, and the least developed application was in the field of Dermatology + Plastic Surgery with $0.9 \%$. When the status of whether the application is paid is examined, it was determined that $66.2 \%$ were free, and when we evaluate their languages, it was determined that $99.5 \%$ applications were in English.

Today the use of smartphones has increased in various forms such as communication, entertainment, and health applications. Most of the applications in the field of health are easily accessible by the society. Health applications such as the side-effects of drugs, calorie intake, weight loss could be given as examples to these applications ${ }^{8}$.
In the studies that were conducted beforehand, it was indicated that, in the context of community health and health service, the mobile phones were used for collecting and blending the data and supporting the health education of the community 9,10 .

Some studies emphasize the success of the use of mobile phones in telemedicine and remote health services implemented in developed countries. The support and follow up of treatment of HIV patients in hard to reach rural areas could be given example to this ${ }^{11,12}$.

Kailas and his friends indicated that currently there is more than 7000 application in the field of health 13. There are comprehensive studies that emphasize various advantages of mobile phones and hand-held computers in health and clinical applications compared to other communication and information technologies, such as portability, uninterrupted data flow, and strong operating system supporting multimedia software applications ${ }^{14,15}$. Besides, significant economic benefits of telemedicine and remote-health applications were reported ${ }^{16}$.

In the mobile health industry market, which was the US $\$ 33.59$ billion in 2017, while the European Union countries were the most active countries, the activity of African regions was low. The development of mobile healthcare is in line with 
the income levels and developments of countries. Mobile Health applications developed by the Ministry of Health of Turkey, center physician appointments system, e-pulse, drug tracking system, 112 emergency help button, vaccine tracking system, ats mobile vaccination is brushing with and without health communication center. In order to get the most out of mobile technology in healthcare in countries, all stakeholders, such as the government, regulators and mobile operators such as healthcare providers, need to work together ${ }^{17}$.

Whereas the smartphone applications with dermatology content could be in the form of reference materials of up to date dermatology books and journals, and visual training information of dermatology diseases, these could also be in the form of dermatologic surveys, disease magnitude score scales and electronic dermatoscopy that enables for photo analysis of skin lesions. By means of these mobile phones that demonstrate the specifications of advance technology, the data could be both stored and transferred ${ }^{6}$. Besides, there are many smartphone applications used for diagnosing various skin diseases and early detection of such diseases and melanoma, through which the patients could remotely consult the dermatology specialists (teledermatology), the patients could detect whether the suspicious skin lesions are benign or malign, and the patients could be informed accordingly ${ }^{8}$.

Whereas the smartphones have the advantages of easy use of mobile applications, ability to take and store photo, capacity to make automatic analysis for skin cancer scanning, ability to compare stored photos, saving from time in daily life and teleconsultation possibility; they also have such disadvantages as ethical problems (confidentiality, privacy), problem of quality in photo taking, less storage capacity, short battery life, information security, and the phone rates and speed problem ${ }^{6}$.

As a conclusion, although it might be seen that the technological devices make our lives easy from many aspects, the story and physical examination are very important in the patient-physician relationship. However, due to such reasons as problems of patients in accessing the physician, more frequent follow up of patients and easily follow up of diseases, and early diagnosis, mobile health applications could be used in the field of dermatology. It is necessary that such type of mobile applications are prepared professionally and their content quality and control are conducted. In general, dissemination of these applications, which make it easy for the physicians, medical students, patients and those who access the applications to reach up to date information, in the field of dermatology could be considered as a positive finding.

\section{REFERENCES}

1. Tezcan C. Sağlığa Yenilikçi Bir Bakış Açısı: Mobil Sağlık. 2016 Yayın No: Tüsiad$\mathrm{T} / 2016-03 / 575$.

2. WHO, World health statistics 2018: monitoring health for the SDGs, sustainable development goals.

3. www.tuik.gov.tr/PreIstatistikTablo.do?istab _id $=2605$

4. Ertek S. Endokrinolojide Tele-Sağlık ve Tele-Tip Uygulamaları. Acıbadem Üniversitesi Sağlık Bilimleri Dergisi 2011, 2:3.

5. World Health Organization. mHealth New Horizons for Health Through Mobile Technologies, Global Observatory for eHealth Series.2011, Volume 3. ISBN 978 924156425 0. Switzerland.

6. Önder M, Narin B. Ak1llı telefonlar ve mobil uygulamaların (Apps) dermatolojide kullanımı. Türk derm. 2013; 47: 1-6.

7. Boulos MN, Brewer AC, Karimkhani C, Buller DB, Dellavalle RP. Mobile medical and health apps: state of the art, concerns, regulatory control and certification. Online Journal of Public Health Informatics, 2014, 5(3): 229.

8. Wolf JA, Moreau JF, Akilov O, Patton T, English JC 3rd et AL. Diagnostic Inaccuracy of Smartphone Applications for Melanoma Detection. JAMA Dermatol. 2013;149(4):422-426.

9. Blaya JA, Fraser HS, Holt B. E-health technologies show promise in developing countries. Health Affairs 2010, 29:244-251.

10. Lindquist AM, Johansson PE, Petersson GI, Saveman B-I, Nilsson GC. The use of the Personal Digital Assistant (PDA) among personnel and students in health care: a review. Journal of Medical Internet Research 2008, 10:31.

11. Kaplan W. Can the ubiquitous power of mobile phones be used to improve health outcomes in developing countries? Global Health, 2006, 2:9.

12. Fraser HSF, Jazayeri D, Nevil P, Karacaoglu Y, Farmer PE, Lyon E, Smith Fawzi MK, 
Leandre F, Choi SS, Mukherjee K. An information system and medical record to support HIV treatment in rural Haiti. BMJ 2004, 329(7475):1142-1146.

13. Kailas A, Chong CC, Watanabe F. From mobile phones to personal wellness dashboards. IEEE Pulse 2010, , 7/8: 57-63.

14. Free C, Phillips G, Felix L, Galli L, Patel V, Edwards P. The effectiveness of M-health technologies for improving health and health services: a systematic review protocol. BMC Research Notes 2010, 3:250.
15. Terry M. Medical apps for smartphones. Telemed J E Health 2010, 16(1):17-22.

16. Noel HC, Vogel DC, Erdos JJ, Cornwall D, Levin F. Home telehealth reduces healthcare costs. Telemed J E Health 2004, 10(2):170183.

17. Saygılı M. Mobil Sağlık. Mustafa Said Yıldız (Ed.) Sağlıkta İleri Teknoloji Uygulamaları içinde 2019, (s.211-235). Ankara: Nobel Yayınevi. 